\title{
PENDEKATAN KONSEP MIMESIS UNTUK MENINGKATKAN KEMAMPUAN MAHASISWA FAKULTAS PENDIDIKAN BAHASA INGGRIS UNIVERSITAS MUSLIM NUSANTARA AL-WASHLIYAH MEDAN DALAM MENGEKSPRESIKAN IDE KEDALAM BENTUK KARYA SASTRA
}

\author{
Zulfitri \\ Universitas Muslim Nusantara Al-Washliyah \\ Kampus A: Jl. Garu II No. 93, Kampus B: Jl. Garu II No.2 \\ zulfitrissma681gmail.com
}

\begin{abstract}
Abstrak
Penulisan makalah ini bertujuan untuk membantu mengatasi permasalahan mahasiswa dan meningkatkan kemampuannya dalam menciptakan sebuah karya tulis khususnya karya tulis dalam bentuk kesusastraan Inggris, untuk itu mahasiswa perlu diberikan bekal pengetahuan yang cukup mengenai salah satu konsep dalam kesusastraan yaitu Mimesis yang mana ini bisa diterapkan dalam menciptakan atau menghasilkan karyakarya tulisan dalam kesusastran Inggris.
\end{abstract}

Kata kunci : mimesis, ide-ide, ekspresi, kesusastraan, karya sastra, penelitian tindakan kelas

Abstrack

Writing this paper has purposes to help the students solve the problem and improve their ability in creating a work, especially the writings in the form of English literature, for that students need to be given sufficient knowledge about one of the concepts in literature that is Mimesis which can be applied in creating or producing literary works in English literature.

Key words : mimesis, ideas, expression, English Literature, literary works, class activity reasearching

\section{Pendahuluan}

\subsection{Latar Belakang}

Meskipun mahasiswa FKIP Bahasa Inggris tidak banyak mempelajari mata kuliah di bidang kesusastranan, tetapi mereka juga harus mampu dan bisa menciptakan sebuah karya tulisan dalam bentuk kesusastran seperti mampu menciptakan dan menuliskan sebuah puisi, mampu menciptakan sebuah novel ataupun cerpen ataupun pandai membuat teks skenario film-film pendek, dll. Karena pada dasarnya kemampuan tersebut tidak hanya kita peroleh kalau kita mengambil kuliah di bidang atau jurusan sastra saja. Kemampuan menciptakan sebuah 
karya sastra itu pasti ada pada semua manusia yang yang mempunyai akal pikiran, daya khayal ataupun imajinasi. Yang membedakannya adalah hanya bakat dan kreatifitas manusia tersebut. Dalam hal ini tentunya seorang mahasiswa adalah seorang akademika yang lebih tingggi daya pikir dan daya kreatifitasnya, tinggal hanya di arahkan berdasarkan ilmu pengetahuan mengenai kesusastraan yang mendukung. Selain itu salah satu tujuan dari program studi pastinya untuk menghasilkan lulusan yang memiliki kompetensi yang baik bukan hanya dalam teori kependidikan saja tetapi dalam berbagai aspek ilmu bahasa Inggris yaitu lingustik dan kesusastraan.

Untuk mengembangkan kompetensi mahasiswa dalam bidang kajian sastra Inggris, ada beberapa mata kuliah yang diberikan antara lain pengantar kajian sastra inggris, kajian prosa dan kajian drama Inggris. Mata kuliah tersebut diajarkan kepada mahasiswa untuk mengasah keterampilan yang bisa mengembangkan kompetensi mereka dalam bidang kesusastraan Inggris. Mungkin bagi beberapa mahasiswa
FKIP Bahasa Inggris berpendapat bahwa mempelajari mata kuliah di bidang kajian sastra Inggris begitu menyulitkan ataupun tidak ada manfaatnya karena hampir semua mahasiswa lulusan FKIP Bahasa Inggris berorientasi ingin bekerja sebagai guru ataupun pengajar di sekolah-sekolah jadi mereka lebih cenderung menyukai ilmu-ilmu tentang teori-teori kependidikan atau mengajar. Hal ini didasari oleh hasil pengamatan peneliti yang mana sudah beberapa kali menyampaikan mata kuliah dalam bidang kajian sastra pada kelas-kelas yang bukan pada jurusan sastra Inggris. Terkadang tidak sedikit juga mengatakan mempelajari mata kuliah di bidang kajian sastra Inggris begitu membosankan, membuat ngantuk dan lain-lain. Kemungkinan, kurangnya kemampuan dalam berpikir kritis, menganalisa inilah yang mempengaruhi tingkat kebosanan dalam mempelajari mata kuliah dalam bidang kajian sastra ini dan ini juga dapat mempengaruhi dalam kompetensi mereka dalam bidang kajian sastra.

Hal inilah yang mendasari pikiran peneliti untuk segera 
melakukan tindakan untuk mengatasi masalah ini. Peneliti ingin menggali bakat-bakat mahasiswa yang terpendam yang tidak pernah terasah ataupun diarahkan dalam bidang kesusastraan dengan menugaskan mereka untuk mengekspresikan ideide kreatif atau daya imajinasi mereka ke arah positif untuk menghasilkan atau menciptakan karya dalam bentuk kesusastraan seperti puisi ataupun menulis sebuah cerita pendek fiksi atau nonfiksi dengan menggunakan konsep mimesis yang telah dipahami.

\subsection{Tujuan Penelitian}

Penelitian ini bertujuan untuk menguji bahwa pengetahuan tentang teori sastra dalam menciptakan karya sastra dalam bentuk tulisan seperti puisi, drama, prosa pada mahasiswa/i subyek penelitian akan meningkatkan kemampuan mereka dalam bidang kajian sastra dan menambah khasanah atau variasi ilmu yang mereka peroleh dalam perkuliahan. Dari penelitian dengan menggunakan pendekatan teori sastra yaitu mimesis ini akan dicoba digali sejauh mana keefektifan pengetahuan tentang karya karya sastra dalam bidang kajian sastra Inggris.

\section{Metode}

Penelitian ini merupakan penelitian deskriptif kualitatif. Penelitian ini bersifat deskriptif kualitatif karena menjelaskan analisis dan hasilnya dengan katakata bukan angka. Dalam hal ini fokus mengajak mahasiswa/i untuk menggali ide kreatifitas / daya imajinasi untuk menciptakan sebuah karya sastra dengan cara menggunakan pendekatan mimesis yaitu sebuah teori dalam ilmu kajian sastra dengan obyek lingkungan Kelas serta kampus Universitas Muslim Nusantara Al-Washliyah Medan.

Adapun teknik yang di lakukan dalam penelitian ini dengan menggunakan pendekatan konsep mimesis yaitu dilakukan dalam beberapa langkah yaitu :

Pada tahap pertama yaitu dilakukan brainstorming mengenai tentang kesusastraan, dari definisi, sejarah maupun jenis-jenis dari kesusastraan

Tahap kedua yaitu pertemuan mulai mengetahui konsep ataupun teori-teori yang ada dalam Kesusastraan Inggris khususnya konsep mimesis, siswa di minta 
memahi konsep ini dan mengambil kesimpulan dari pemahaman yang diperoleh di kelas didukung oleh literatur-literatur yang lain yang mereka dapat baik dari library research ataupun internet research.

Tahap ketiga yaitu pertemuan mulai siswa di ajak menggali ide-ide kreatif pikiran mereka untuk menciptakan sebuah karya sastra baik berupa puisi, prose atau drama dengan menggunakan pendekatan konsep mimesis yang telah mereka pahami bersama.

$\begin{array}{llr}\text { Tahap keempat } & \text { yaitu } \\ \text { pertemuan siswa } & \text { mulai } \\ \text { mempresentasikan } & \text { hasil } & \text { kerja } \\ \text { mereka serta } & \text { siswa } & \text { diajak }\end{array}$
mengkritisi hasil kerja temannya, selanjutnya di lakkan evaluasi serta membuat kesimpulan dari hasil kerja siswa dengan didukung oleh teori yang telah dipelajari.

\section{Hasil Dan Pembahasan}

\section{Analisis terhadap pemahaman teori sastra mimesis}

Dari hasil analisis terhadap penjelasan serta sejauh mana pemahaman mengenai teori sastra mimesis yang telah diterima oleh mahasiswa/i di semester VA dan VB fakultas pendidikan Bahasa Inggris
Universitas Muslim Nusantara AlWashliyah Medan didapati hanya $50 \%$ dari 50 peserta yang ikut dalam kegiatan ini yang dapat melakukan dan membuat hasil kerja/karya yang mengacu kepada topik teori mimesis yang telah dijelaskan dan dipahami bersama sesuai intruksi. Sementara $50 \%$ nya lagi mahasiswa/i dapat menyelesaikan kerja/karya nya tetapi belum tepat sesuai dengan pemahaman teori sastra mimesis yang sebenarnya di perintahkan. Hasil - hasil karya sastra yang telah dibuat mahasiswa/i tersebut terbagi dalam kelompok lagi, yaitu karya sastra puisi dan prosa ( cerita pendek ). Secara lebih jelas, jenis dan jumlah hasil karya yang dikerjakan mahasiswa dapat dilihat dalam tabel berikut ini.

\begin{tabular}{|c|l|c|}
\hline & Jenis karya sastra & Jumlah \\
\hline 1 & Umum & 50 \\
\hline 2 & Puisi & 15 \\
\hline 3 & Prosa ( cerita pendek ) & 10 \\
\hline 4 & Puisi & 20 \\
\hline 5 & Prosa ( cerita pendek ) & 5 \\
\hline
\end{tabular}

Tabel 1. Jenis, Jumlah, dari hasil kerja/karya mahasiswa

Tabel di atas menunjukkan bahwa sebenarnya mahasiswa/i sudah mempunyai bakat/ide - ide dalam menciptakan sebuah karya sastra, mereka dapat menuangkan 
ide/daya imajinasi mereka kedalam bentuk hasil karya tulisan baik itu berupa puisi maupun prosa/ cerita pendek. Dalam proses analisis terhadap pemahaman teori mimesis yang mana pada dasarnya keseluruhan mahasiswa/i dapat memahami mengenai apa yang dimaksud dengan teori sastra mimesis, tetapi hanya setengah dari jumlah peserta yang dapat dengan baik menghasilkan karya sastra sesuai dengan petunjuk yang telah diperintahkan.

\section{Analisis terhadap jenis karya} sastra

Petunjuk “ Buatlah

/ciptakanlah sebuah karya sastra

b. petunjuk

tema/judul dari puisi - puisi tersebut yaitu :

Trees,

The Lamp,

My Teacher,

Fan,

Shine,

Smile,

The One Best Friend,

Lecture,

My Classmate. berupa tulisan baik itu puisi ataupun prosa dengan menggunakan pendekatan teori mimesis yang mana fokus pada lingkugan kelas anda serta lingkungan Universitas Muslim Nusantara al-Washliyah Medan".

Dari petunjuk tersebut maka mahasiswa/i semester VA dan VB, menciptakan sebuah karya sastra berbentuk tulisan yaitu berupa puisi maupun prosa. Dari hasil kerja mahasiswa/i maka penulis mengkategorikan hasil $\quad-$ hasil tersebut serta menguraikan dengan penjelasan - penjelasa sebagai berikut :

a. Kelompok yang menciptakan hasil karya sastra puisi sesuai

Mahasiswa/i yang berhasil menciptakan karya sastra

c. Kelompok yang menciptakan hasil karya sastra prosa sesuai petunjuk

Mahasiswa/i yang berhasil menciptakan karya sastra tersebut berjumlah 10 orang, yang mana

tema/judul dari prosa yaitu :

Class,

My favourite Lecturer,

My Classroom,

My University,

My Motorcycle, My Horse,

My phone,

Campus, 
Etc.

c. Kelompok yang menciptakan hasil karya sastra puisi belum sesuai petunjuk Mahasiswa/i yang menciptakan karya sastra puisi tersebut berjumlah 16 orang, yang mana tema/judul dari puisi yaitu :

Miss my family, Destiny,

My lovely cat, Hold a dream, At the beach,

Etc.

My House,

My Lovely Doll, My Family, Etc.

\section{Kesimpulan}

Berdasarkan hasil analisis terhadap hasil karya sastra berupa tulisan puisi atau prosa (cerita pendek) yang telah dilakukan mahasiswa/i didalam pemahaman mengenai pendekatan teori sastra mimesis dapat disimpulkan bahwa mahasiswa/i pada dasarnya hampir seluruh dapat memahami mengenai penjelasan mengenai pendekatan teori sastra mimesis yaitu : Pendekatan mimetik atau mimesis adalah pendekatan kajian sastra yang menitikberatkan kajiannya terrhadap hubungan karya sastra dengan kenyataan di luar karya sastra. Pendekatan yang memandang karya sastra sebagai imitasi dari realita (Abrams dalam Siswanto, 2008:188). d. Kelompok yang menciptakan hasil karya sastra prosa yang belum sesuai petunjuk Mahasiswa/i yang berhasil menciptakan karya sastra tersebut berjumlah 9 orang, yang mana tema/judul dari prosa yaitu :

My House,

My Lovely Doll, My Family, Etc.

Hasil kerja/karya sastra yang telah dibuat oleh mahasiswa/i menunjukkan bahwa mahasiswa/i sebenarnya mempunyai kemampuan dalam menciptakan sebuah karya sastra yaitu berupa tulisan yaitu dalam bentuk puisi atau prosa/cerita pendek. Tetapi bakat ini seharusnya harus dikembangkan serta ditingkatkan dengan cara selalu melakukan latihan-latihan dengan seringnya melakukan kegiatan menulis dan menciptakan karya apakah itu dalam bentuk puisi, cerita pendek, membuat naskah drama dan lain sebagainya. 


\section{Daftar Pustaka}

Bertens, K. 1979. Ringkasan Sejarah Filsafat. Yogyakarta : Kanisius Departemen Pendidikan Nasional. 2008. Kamus Besar Bahasa Indonesia.Jakarta : Gramedia Pustaka Utama

Luxemberg, Jan Van dkk. 1986. Pengantar Ilmu Sastra. Jakarta : Gramedia (judul asli Inleiding in de literaturur Wetenschap.1982.

Muideberg: Dikck Countinho B.V

Oxford Unversity Press

Nyoman, Kutha Ratna, 2004. Teori, Teknik, dan Metode Penelitian Sastra. Yogyakarta : Pustaka Pelajar
Vitgever. Diterjemahkan oleh Dick Hartoko).

Teew, A. 1984. Sastra dan Ilmu Sastra. Jakarta : Dunia Pustaka Jaya Abrams, M.H. 1976. The Mirror and lamp : Romantic Theory and Critical Tradition. Oxford :

Oxford Unversity Press

Nyoman, Kutha Ratna, 2004. Teori, Teknik, dan Metode Penelitian Sastra. Yogyakarta : Pustaka Pelajar Wellek, Rene \& Warren Austin, 1989.Theory of Literature.

Wellek, Rene \& Warren Austin, 1989.Theory of Literature. 